\title{
Corporate Sustainability and Responsibility in Agro Business: Creating Value for Sustainability in Society and the Environment
}

\author{
Kwame Asare Duffour ${ }^{2}$, Waseem Ahmed $^{2}$ \& Qamar Farooq $^{1}$ \\ ${ }^{1}$ School of Economics and Management, Zhejiang Normal University, Jinhua, China \\ ${ }^{2}$ School of Business Administration, Zhejiang Gongshang University, Hangzhou, China \\ Correspondence: Qamar Farooq, School of Economics and Management, Zhejiang Normal University, Jinhua, \\ China. E-mail: f4farooq@gmail.com
}

Received: May 10, 2021; Accepted: June 10, 2021; Published: June 30, 2021

\begin{abstract}
Scholars and companies are making efforts in broadening the knowledge and image of corporate sustainability and corporate social responsibility. In light of this direction, this paper reports on how agro businesses are affecting the well-being of humans, the environment, and the corporate sector. This study adopted to review published electronic journal articles on corporate sustainability and corporate social responsibility shedding light on the challenges, threats, and solutions of agro-business. Furthermore, the study critically analyzes some of the latest value-based sustainability constructs. This review provides a conceptual understanding of sustainability and corporate responsibility. Responsible business practices foster the creation of economic and social value by realigning business objectives with stakeholder management and environmental responsibility. The study adds to the literature and is a critical insight to organizations regarding sustainability in agro business and corporate social responsibility.
\end{abstract}

Keywords: corporate sustainability, agro business, corporate image, corporate social responsibility

\section{Introduction}

Today's operations and management must combine high standards of environment, health, and wealth with the goals of social justice to maintain the earth's ability to support various forms of life. Sustainability can be defined as the maintenance of well-being, which includes social, economic, and environmental aspects (Kuhlman \& Farrington, 2010). In other words, the concept of sustainability is described as the allocation of limited resources for human consumption, such that the resources do not harm the environment or society. Sustainability is equality between generations, meeting the needs of current and future generations, meeting basic needs, and securing future (Rosen, 2007). Due to limited resources and the presence of environmental pumps on the planet, people are questioning the effectiveness of sustainable growth (Svirezhev, 2000). Sustainability can be summarized in three basic concepts: people, planets, and profit (Elkington, 1994). These three terms can be summed up as the concept of a "triple bottom line". This concept derives from business science and is associated with corporate social responsibility (CSR) (Farooq et al., 2021). In general, while saving the economy, they should be encouraged to care for the well-being of the people of the environment and society. Sustainability is important because it helps reduce packaging and food waste, promote the use of recyclable materials, and improve the management of healthcare, aviation, and shipping.

\section{The Concept of Sustainable Development in Agro-Business}

The concept of sustainable development in agro business leads to three concepts: the concept of development (socio-economic development under environmental constraints), the concept of demand (allocation of resources to guarantee the quality of life of all people), and the concept of future generations (long-term use (potential) resources to guarantee the necessary quality of life for future generations. The term sustainability means "the ability to sustain a particular entity, result or process over time" (Jenkins, 2009: 380), the activities carried out do not run out of resources on which capabilities depend. This means all human activities and business processes, as it is a general understanding of sustainability, as it yields to social and environmental development (Farooq et al. 2020a). Therefore, by general definition, any activity can be executed and modified in large quantities without causing self-destruction but can be updated repeatedly over a long period. However, a general understanding of sustainability is dangerous because Shiva (2010: 240) does not consider environmental constraints or the need for human activity to adapt to the sustainability of natural systems. It is difficult to think about sustainability without 
ecological considerations since the natural system allows people to live and sustain the consequences of human activity (Jenkins, 2009; Sachs, 2010; Shiva, 2010). Therefore, environmental sustainability has become a basic framework for examining social, cultural, and economic sustainability, and it is also controversial in the concept of sustainable development, it has become the goal of.

The essence of the concept of sustainability is the "triple bottom line", that is, ecological sustainability, which consists of three pillars of sustainability aimed at maintaining the quality of the environment required for economic activity to improve the quality of life, sustainability of people and society, search for human rights and equality, maintenance of cultural identity, respect for cultural diversity, race and religion, and economic sustainability. These are necessary to maintain the natural, social and human capital, and necessary to generate and maintain income. Meeting the requirement of living standard is not easy due to the balance of all these pillars to achieve full sustainable development. To achieve this goal, each pillar of sustainability must respect the interests of the other pillars. Therefore, some pillars of sustainable development have become sustainable, while others have become unsustainable, especially in terms of environmental sustainability, which depends on overall development capacity.

\section{Local and Global Challenges of Sustainability}

\subsection{Challenges of Sustainability in Local Businesses}

Local companies around the globe face sustainability problems. The cost of being "green" in business comes with an increase in prices and is further transferred to consumers. In other to be effective and efficient in the industry, businesses should be environmentally friendly through efficient energy usage, operational resources, and supply chain.

\subsubsection{The Sustainability Transition}

Sustainability transition is a global challenge being faced by the world. Researchers' findings showed that societynature interactions are not met, thus detrimental to the ecological systems and welfare of humans in irreversible directions, causing long-term damage (UNEP, 2007). According to the results of the 2007 UNEP survey, communities and societies have human needs and their basic aspects without affecting the survival system on earth and without easily having limited resources. They should be able to integrate. Rather, it is human development and necessary ecosystem services that must be maintained.

\subsubsection{Regulation for Sustainability}

On the local front, the problem of sustainability lies in the hands of the government (Adger and Jordan, 2009). Sustainability transition cannot be accomplished if governmental institutions and influencing regulations do not make a collective decision. Thus, institutions and teams living at the expense of limited resources under the law or will be convinced to lose at the expense of future generations. The main responsibility of the government is to provide regulatory networks which recruit affected institutions to broaden their sustainability rule-making enforcement (Mason and Michael, 2011).
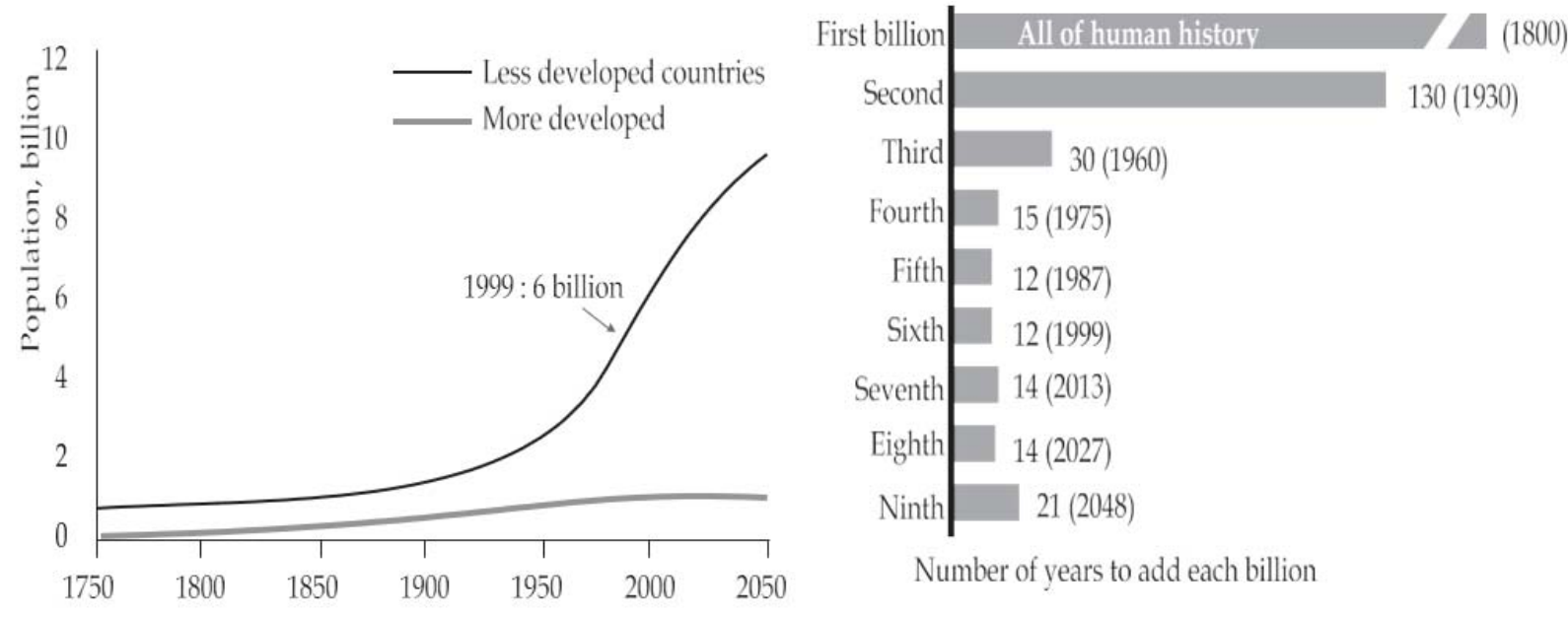

Figure 1. (Source: Subramanian, 2007) Population trend from 1750-2050 


\subsubsection{Environmental Threats}

An environmental threat is one of the main challenges to sustainability on earth. Urbanization has resulted in a large number of populations, energy use, and global warming, shortage of resources in production, soil, air, and transportation, etc. Statistically, in the year 2000, the world urban population had amounted to over 2.9 billion, and it has risen significantly by the mid of 2021. Projections are that Asia will occupy the world's urban population by 2030 as well as an increase in inhabitants in the African context (Subramanian, 2007).

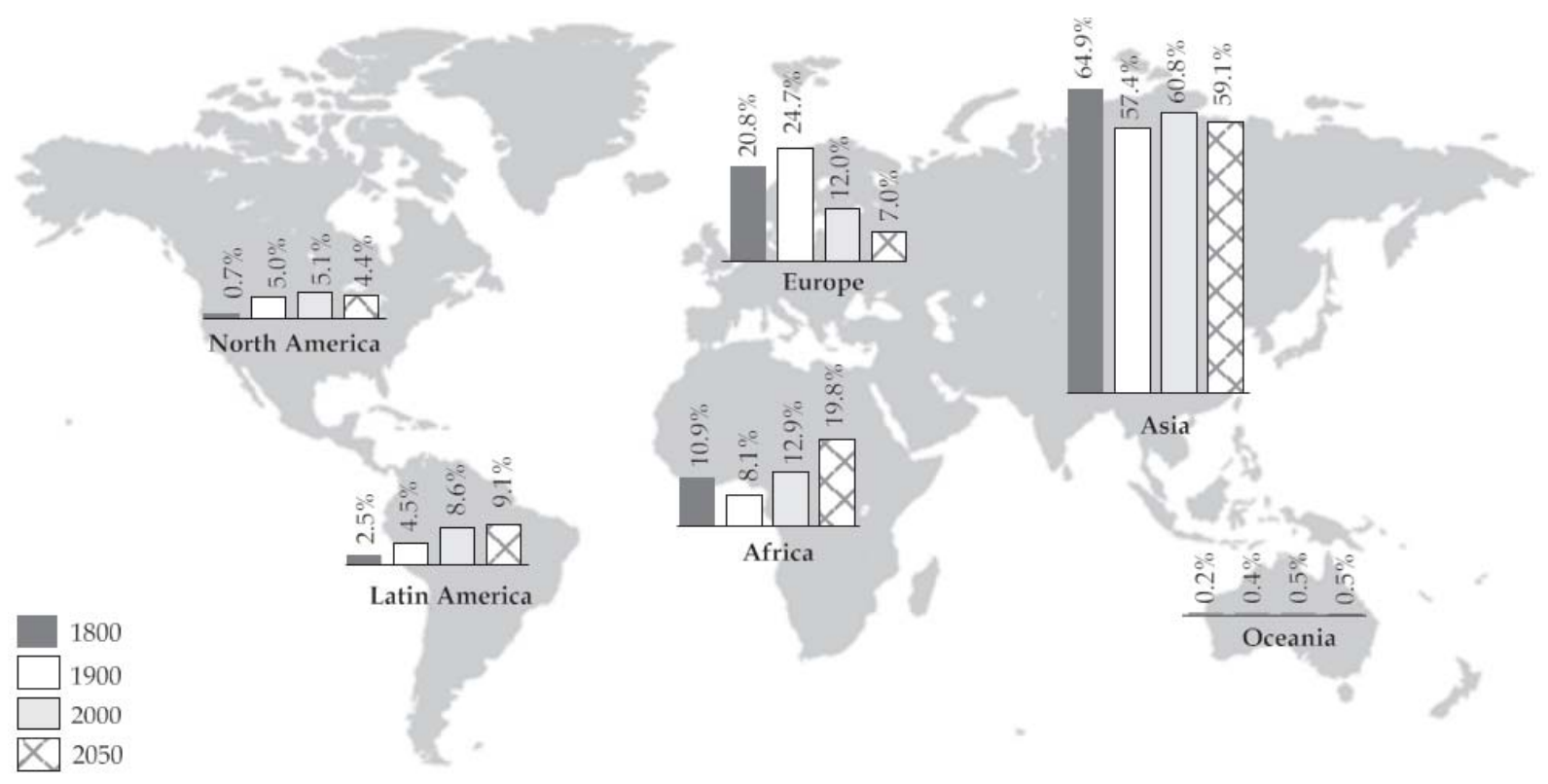

Figure 2. (Source: Subramanian, 2007) Distribution of world population.

\subsubsection{Energy Consumption and Global Warming}

From the perspective of energy challenges for sustainable development and global warming, the world consumes $15 \mathrm{TW}(15 \times 1012 \mathrm{~W})$, of which $86.5 \%$ are fossil fuels (oil, coal, natural). It is due to gas combustion). It causes greenhouse effect and population growth that ultimately causes global warming. According to the US Department of Energy's forecast of the international energy outlook for 2030, the accumulation of China and India accounts for almost half of the total increase in total residential energy consumption in non-OECD countries (Subramanian, 2007). Figure 3 shows the contributions of the various energy sources in the world.

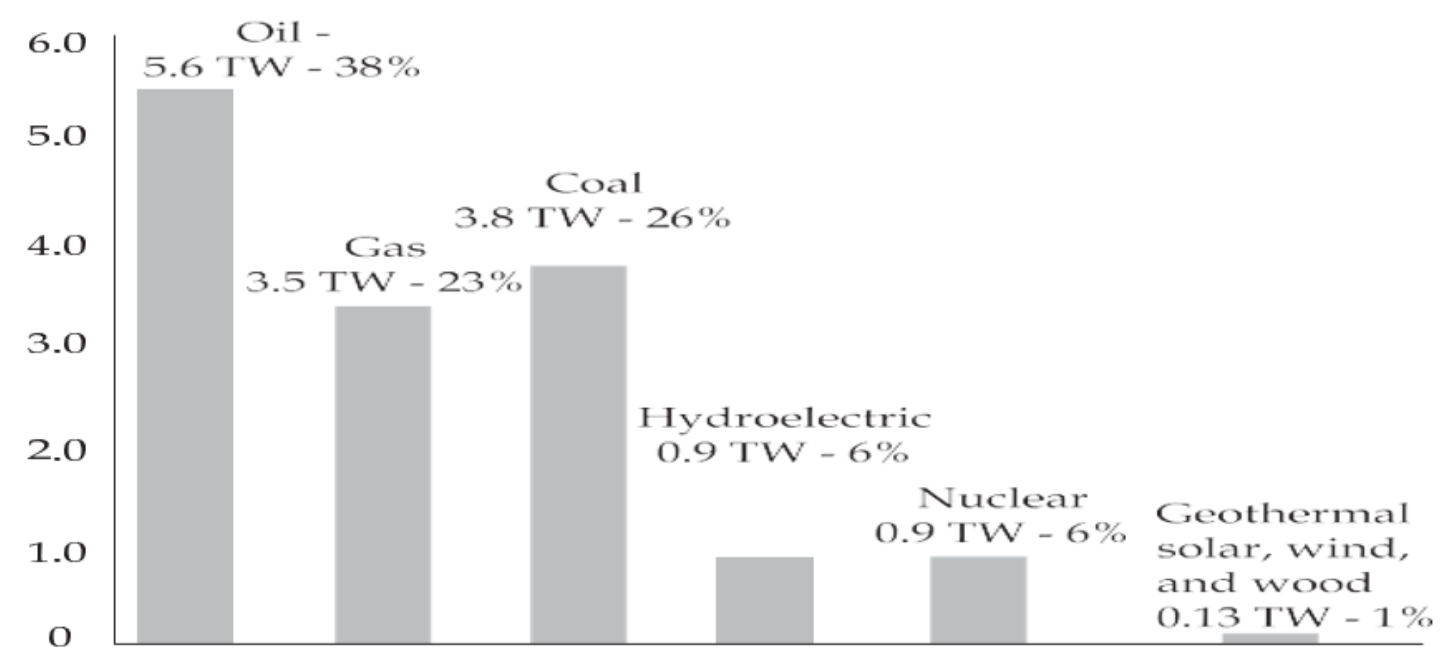

Figure 3. Worldwide energy supply in TW.

Source: Energy Information Administration, US Department of Energy, 2004. 


\subsection{Reason for Change in Sustainability}

The future is expected to happen as various solutions can be implemented to reduce sustainability issues for society and the world at large. In other regions of the world, some recommendations have been adopted and successfully implemented in anticipation of other regions of the world. More importantly, these solutions can be the driving force behind solving sustainability problems. Solar thermal power plants, chemical storage of electricity (batteries and fuel cells), non-fossil methane, vegetable oils, advanced biomass gasification. The implementation of the above solution has its strengths and weaknesses in sustainability management (Subramanian, 2007). Additionally, the motivation to change sustainability comes from companies that see compliance as an opportunity. Therefore, the company is obliged to comply with the laws established by the authorities. Laws on environmental regulations are different. For example, in 2007 San Francisco banned supermarkets from using plastic bags at the checkout, but San Diego has not yet done so. By complying with standards, rules, and regulations, companies have a significant competitive advantage in driving innovation and business opportunities (Ram et al., 2009). Likewise, companies are motivated by the sustainability of the change in their value chain systems. In other words, the company is focused on reducing the consumption of non-renewable resources such as oil, coal, natural gas, and other renewable resources, such as water. The company strives to build a good corporate image, reduce manufacturing and production costs, and create new business opportunities. By analyzing all links in the value chain, companies can create sustainable development chains. Companies make changes in obvious areas, such as the supply chain, before moving to less obvious and suspicious areas, such as product returns (Ram et al., 2009).

\subsection{Agriculture Sector of United Kingdom (UK)}

In the UK, agriculture has become a priority in other areas of the country's economic development, as the economy is the largest contributor to domestic food consumption. Overall, agriculture contributed $£ 24$ billion in revenue to the UK economy in 2015, adding around $£ 8.5$ billion to the total value of production (Development Economics, 2017). 475,000 jobs were created directly in the agricultural sector, and the ministry supported more than 30,000 jobs through contracting activities (transportation, manufacturing, construction, and other financial services, etc.) (Development Economics, 2017).

\subsubsection{Sustainable $\mathrm{CO} 2$ emissions in the UK}

This study looks at the UK agriculture sector and focuses on reducing and eliminating carbon emissions. Dependence on agricultural products such as pesticides and fertilizers has recently increased people's desire to improve their agricultural sector. In addition, the ministry relies on government support to subsidize agricultural inputs and outputs, as well as lower prices for products it creates related to life, pollution, and adverse habitat effects. In agricultural production, sustainable agriculture can benefit communities without damaging the environment, conserving limited resources, and using them economically. The call to solve economic growth through the consumption of materials and energy is also useful as a countermeasure against environmental problems. However, increasing the intensity of the service can be used, which increases the consumption of energy and materials.

\subsubsection{Greenhouse Gas Emissions and Food Economics}

The agricultural sector and its products (such as fertilizer production and land use) account for one-third of gas emissions. Therefore, the basic production of agricultural goods, which generates greenhouse gas emissions, is very different from that of other industries. In addition, the production of cattle and sheep also affects global warming due to the methane they produce. In the UK, carbon dioxide emissions from the agricultural sector account for $7 \%$ of total emissions, including food processing, agricultural production, distribution, and retail (HM Government, 2006). According to the EU Environmental Product Impact Report (EIPRO), food is responsible for $20-30 \%$ of environmental problems. These correspond to $4-12 \%, 2-4 \%$, and $1 \%$ of meat, dairy products, and serials respectively (Tukker et al., 2006; Steinfeld, H et al., 2006). Furthermore, organic food production accounts for the majority of the global food system (Sustain, 1999). As a result, handling, packaging, and transportation are receiving a great deal of attention, as intermittent trade-offs between agriculture and the agricultural environment are a top priority today. Also, food transportation affects food contamination and energy consumption. The pollutants that affect mileage are Carbon Dioxide (CO2), Methane (CH4), Nitrous Oxide (NOx), and Volatile Organic Compounds (VOC). The Intergovernmental Panel on Climate Change (IPCC) recommends reducing the UK's annual carbon emissions of 150 million tons by at least $60 \%$ (Sustain, 2001). However, the UK can take the following steps to reduce and eliminate carbon emissions from the agricultural sector: First, due to increased concentration and efficiency of production, part of the land was used as temporary pasture and small lands were converted to forests, shrinking by about $10 \%$. Second, it is reduced by about $33 \%$ by reducing the level of production of carbon-intensive products, where the unused land is mainly used for grazing. Third, by reducing 
production levels and switching to less carbon-intensive products, the released land is mainly used as pasture, accounting for $46 \%$. The table below shows greenhouse gas emissions from the UK's top food production.

Table 1. Greenhouse gas emissions from the primary production of food for consumption in the UK.

\begin{tabular}{lc}
\hline Food category & kt CO2e \\
\hline Red meat & 19,400 \\
Milk & 17,200 \\
White meat & 10,900 \\
Cereals, including for brewing and distilling & 9,750 \\
Vegetables \& legumes & 5,380 \\
Oil-based crops & 4,060 \\
Salad crops & 3,580 \\
Fish & 2,780 \\
Grapes \& wine & 2,610 \\
Temperate \& Mediterranean fruit & 2,220 \\
Rice & 1,860 \\
Exotic fruit & 1,780 \\
Eggs & 1,650 \\
Sugar & 1,200 \\
Beverages & 1,180 \\
Nuts & 254 \\
Misc. including spices & 79 \\
Total & 85,883 \\
Gas emitted (\% of total GWP from primary \\
production) & \\
Carbon dioxide CO2 & $(54 \%)$ \\
Nitrous oxide N2O & $(24 \%)$ \\
Methane CH4 & $(22 \%)$ \\
\hline
\end{tabular}

Source: Adapted from (Audsley et al, 2009).

\subsubsection{Renewable Energy}

In the UK, farmers are investing heavily in renewable energy production, increasing by a third of the total number of farmers in the country, including wind, solar, and biomass power (DECC Renewable Energy, 2015). Therefore, the main source of onshore wind power is the installed capacity of farmland in the UK. In addition, in the field of solar energy, the NFU expects farmers to provide $60 \%$ of the UK's installed capacity. Considering the energy from agricultural biomass, animal and plant biomass, anaerobic substances constitute 5.3 million tons of oil (DECC Renewable Energy, 2015). Based on the fact that each tone of oil equivalent used for energy production is associated with the production of 3.08 tons of carbon dioxide, renewable energy produced on UK farms saves 21.9 million tons of carbon dioxide equivalent. Yes (DECC Renewable Energy, 2015).

\subsection{Areas to Replace Primary Energy Demand}

\subsubsection{Supply Chain Emissions}

Reduction in emissions requires possible measures: energy, consumption, and technology. In terms of emissions, removing food waste from the system can reduce emissions by $15 \%$. Therefore, converting energy-related emissions to carbon-free fuels improves energy efficiency. By 2050, consumption, emissions, and other regions will be reduced by $59 \%, 55 \%$, and $70 \%$ respectively (Smith, 2007). In the case of food, emissions excluding landuse change were $56 \%$. In addition, the energy used in various sectors of the economy (agricultural inputs, agriculture, processing and storage of raw materials, etc.) has a high proportion of carbon dioxide emissions. A comprehensive assessment can reduce supply chain emissions. Recently, the government has focused on $80 \%$ of the economy and is acting to tackle decarbonization and energy efficiency by 2050 .

\subsubsection{Irrigation}

Irrigation can be a high-risk activity that replaces the demand for primary energy in the agricultural sector. It occupies about $10 \%$ of the world's arable land (about $300 \mathrm{Mha}$ ), supplies water to pumps, and consumes $0.225 \mathrm{EJ}$ 
per year. In addition, the production of irrigation equipment requires about $0.05 \mathrm{EJ} /$ year of indirect energy (Smil, 2008). Compared to rainwater systems, irrigation is preferable because it can produce more crops and accounts for about $40 \%$ of the global cereal supply (FAO, 2011). Lack of funding hinders the use of irrigation in Africa. In India, irrigation still releases water, resulting in $3.7 \%$ of total greenhouse gas emissions in 2000 (58.7 tonnes of carbon dioxide equivalent) (Nelson et al., 2009). Energy-intensive electricity is estimated to increase by $87 \%$ by 2050 due to the depletion of shallow water.

\subsubsection{Protected Crops}

Greenhouse design to produce vegetables, fruits and flowers will help replace the UK's primary energy needs. Production systems include closed-loop or hydroponic systems that can transport water and nutrients without the use of crops in the soil. These installations rely solely on powerful direct energy inputs such as lighting and heating. The fresh production input of tomatoes and other crops is $40 \mathrm{MJ} / \mathrm{kg}$ (FAO, 2011). For example, China and South Korea use less energy than energy-intensive heating greenhouses used in the west and other parts of the world, resulting in simpler, shady homes. In summary, using the greenhouse design, the energy intensity of a crop can be 10-20 times greater than that of the same crop on the farm (Saunders \& Hayes, 2009).

\subsubsection{Barn}

In the agricultural sector, animal shelters can be used effectively to efficiently retain energy and maintain optimal temperature and humidity (GoS, 2011). Computer-controlled power systems can reduce waste supply and lower overall power requirements. There are also options to reduce the energy input required for water and heating, drying, food storage, and transportation equipment.

\section{Conclusion}

This study aimed to contextualize the concept of sustainability, local and global sustainability challenges, motivations for sustainable change, sustainable carbon emissions, and demand for alternative primary energy in agro-businesses. In the above discussion, world food production is expected to increase by $70 \%$ by 2050 to meet the global demand for food. When supply demand intersect, prices remain the same; thus, costs for fossil fuels will remain the same, and demand for food will be the same; therefore, greenhouse gas emissions will be reduced. This shows that rise of fossil fuels has a profound effect on increasing greenhouse gas emissions. Policies and regulations can be strengthened and implemented to enable the agricultural sector to address unforeseen energy supply problems and their impact on climate change. Central and local governments should review policies, regulations, and procedures to guide and manage rural development, combine food security and energy security, and achieve the objectives of sustainable development to reduce carbon dioxide emissions.

\section{References}

Adger, W. N., \& Jordan, A. (eds) (2009). Governing Sustainability, Cambridge University Press, Cambridge. https://doi.org/10.1017/CBO9780511807756

Audsley, E., Brander, M., Chatterton, J., Murphy-Bokern, D., Webster, C., \& Williams, A. (2009). How low can we go? An assessment of greenhouse gas emissions from the UK food system and the scope to reduce them by 2050. WWF-UK.

DECC Renewable Energy in 2015 published (June 2016). Retrieved from https://www.gov.uk/government/statistics/energy-trendsjune-2016-special-feature-article-renewable-energyin-2015.

Elkington, J. (1994). Towards the sustainable corporation: Win-win-win business strategies for sustainable development. Calif. Manage. Rev. 1994, 36, 90-100. https://doi.org/10.2307/41165746

FAO. (2011). Save and grow - a policy maker's guide to the sustainable intensify cation of smallholder crop production. Plant Production and Protection Division, Food and Agriculture Organization of the United Nations, Rome. 101 pages.

Farooq, Q., Fu, P., Liu, X., \& Hao, Y. (2021). Basics of Macro to Micro-Level Corporate Social Responsibility and Advancement in Triple Bottom Line Theory. Corporate Social Responsibility and Environmental Management. https://doi.org/10.1002/csr.2069.

Farooq, Q., Hao, J., Liu, X., Xiao, D., \& Hao, Y. (2020a). Social and Environmental Development: Fresh Concepts and Soft Measures towards Sustainable Development. Sustainable Development, 28(6), 1796-1803. https://doi.org/10.1002/sd.2075.

Farooq, Q., Liu, X., Fu, P., \& Hao, Y. (2020). Volunteering Sustainability: An Advancement in Corporate Social 
Responsibility Conceptualization, Corporate Social Responsibility and Environmental Management, 27(6), 2450-2464. https://doi.org/10.1002/csr.1893

GoS. (2011). Foresight project on global food and farming futures, Synthesis Report C12: Meeting the challenges of a low-emissions world, UK Government Offi ce for Science, London. Retrieved from http://www.bis.gov.uk/assets/bispartners/foresight/docs/food-and-farming/synthesis/11-632-c12-meetingchallengesof-low-emissions-world.pdf

HM Government. (2006). Climate change, the UK programme. Retrieved from https://www.gov.uk/government/uploads/system/uploads/attachment_data/file/532963/Renewable_energy_i n_2015.pdf 32

Jenkins, W. (2009). Berkshire encyclopaedia of sustainability: The spirit of sustainability, 1 (1st ed.). Berkshire: Berkshire Publishing Group.

Kuhlman, T., \& Farrington, J. (2010). Sustainability 2010, 2, 3436-3448. https://doi.org/10.3390/su2113436

Mason, Michael (2011). The sustainability challenge. In: Brady, John and Ebbage, Alison and Lunn, Ruth, (eds.) Environmental Management in Organizations. Earthscan, London, UK, pp. 525-532. ISBN 9781849710626

Nelson, G. C., Robertson, R., Msang, S., Zhu, T., Liao, X., \& Jawajar, P. (2009). Greenhouse gas mitigation issues for Indian agriculture. Discussion paper 00900, International Food Policy.

Ram, N., Prahalad, C. K., \& Rangaswami, M. R. (September 2009). Why Sustainability Is Now the Key Driver of Innovation, Harvard Business Review, 57-64.

Rosen, M. A. (2007). Future trends in engineering education. In Innovations 2007: World Innovations in Engineering Education and Research; Int. Network for Engineering Education and Research (iNEER) in cooperation with Begell House Publishers: Arlington, VA, USA, 2007; pp. 1-12.

Sachs, W. (2010). Environment. In W. Sachs (Ed.), The Development Dictionary: A guide to knowledge as power (2nd ed.) (pp. 24-37). London, New York: Zed Books.

Saunders, C., \& Hayes, P. (2009). Air freight transport of fresh fruit and vegetables, Research report 299, Agribusiness and Economic Research Unit, Lincoln University, New Zealand. 48 pages. Retrieved from http://researcharchive.lincoln.ac.nz/dspace/bitstream/10182/248/1/aeru_rr_299.pdf

Shiva, V. (2010). Resources. In W. Sachs (Ed.), The Development Dictionary: A guide to knowledge as power (2nd ed.) (pp. 228-242). London, New York: Zed Books.

Smil, V. (2008). Energy in nature and society- general energetic of complex systems, MIT Press, Cambridge, Massachusetts. 512 pages.

Smith, P., Martino, D., Cai, Z., Gwary, D., Janzen, H., Kumar, P., ...Smith, J. (2007). Greenhouse gas mitigation in agriculture. Phil. Trans. R. Soc. B., 363, 789-813. https://doi.org/10.1098/rstb.2007.2184

Steinfeld, H., Gerber, P., Wassenaar, T., Castel, V., Rosales, M., \& de Hann, C. (2006). Livestock's long shadow. FAO.

Subramanian, N. (2007). Sustainability challenges and solutions. The Indian Concrete Journal, December, 2007.

Sustain. (1999). Food Miles: Still on the Road to Ruin? Sustain, London

Sustain (2001). Eating Oil - Food in a Changing Climate Sustain, London

Svirezhev Y. M. (2000). Thermodynamics and ecology, Ecological Modelling, 132: 11-22, 2000. https://doi.org/10.1016/S0304-3800(00)00301-X

The Global Land Outlook, first edition. United Nations Convention to Combat Desertification. 2017. Bonn, Germany.

Tukker, A., Huppes, G., Guinée, J., Heijungs, R., ... Nielsen, P. (2006). Environmental Impact of Products (EIPRO). Analysis of the life cycle environmental impacts related to the final consumption of the EU-25. Main report IPTS/ESTO project.

UNEP. (2007). Global Environment Outlook 4: Environment for Development, United Nations Environment Programme, Progress Press, Valletta, Malta. Retrieved from http://www.unep.org/geo/geo4/report/GEO4_Report_Full_en.pdf 


\section{Copyrights}

Copyright for this article is retained by the author(s), with first publication rights granted to the journal.

This is an open-access article distributed under the terms and conditions of the Creative Commons Attribution license (http://creativecommons.org/licenses/by/4.0/). 